\title{
Investigation of the Effect of Gastroesophageal Reflux Disease on Dental Erosion and Oral Tissue Alterations
}

\section{Gastroözofageal Reflü Hastalığının Dental Erozyona ve Ağız Dokularındaki Değişikliklere Etkisinin Araştırılması}

\author{
Datma Aytaç Bal1, @Engin Ersöz² \\ 'Beykent University School of Dentistry Department of Restorative Dentistry, Istanbul, Turkey \\ ${ }^{2}$ Clinic Dentist, Ankara, Turkey
}

\begin{abstract}
Aim: This study aimed to investigate the relationship between gastroesophageal reflux disease (GERD) and dental erosion and the alterations in oral tissues.

Material and Method: In this study, the GERD group consisted of 50 individuals with gastroesophageal reflux symptoms, and the control group consisted of 50 healthy individuals. The prevalence of teeth wears and caries was evaluated using the Smith and Knight tooth wear index (TWI) and the decayed, missing, and filled teeth index (DMFT), respectively. Oral complaints were also evaluated. Stimulated saliva samples were collected, and the salivary buffering capacity, $\mathrm{pH}$ and flow rate values were measured.
\end{abstract}

Results: In the GERD group, wear was observed in the palatal surface of the maxillary teeth, whereas no wear was observed in the control group $(p<0.05)$. Although the incisal surfaces of the maxillary anterior teeth and the occlusal surfaces of the maxillary/ mandibular posterior teeth were observed as eroded in both groups, the values in the patient group were significantly higher compared with those of controls $(p<0.05)$. In the GERD group, complaints of inflammatory mouth sensitivity, tongue sensitivity, nonspecific itching and burning, halitosis, dry mouth, tooth sensitivity, erythema in the soft/hard palatinal mucosa/uvula were significantly more frequent than the control group $(p<0.05$, for each). The groups were similar with respect to DMFT $(p=0.480)$. The salivary flow rate, $\mathrm{pH}$ and buffering capacity values were found to be significantly lower in the GERD group ( $p<0.05$, for each).

Conclusion: The results showed that patients with GERD had wear in palatal surfaces of maxillary teeth. Moreover, these patients also complained more commonly from oral tissue alterations and had lower salivary flow rate, $\mathrm{pH}$, and buffering capacity. Hence dentists should consider GERD as a potential risk factor for oral health.

Keywords: Dental erosion, gastroesophageal reflux disease, saliva

\section{Öz}

Amaç: Bu çalışmanın amacı, gastroözofageal reflü hastalığı (GÖRH) ile dental erozyon ve ağız dokularındaki değişiklikler arasındaki ilişkinin araştırılmasıdır.

Gereç ve Yöntem: Çalışmada GÖRH grubu gastroözofageal reflü semptomları olan 50 kişiden, kontrol grubu ise 50 sağlıklı bireyden oluşturuldu. Diş aşınması ve çürük prevalansı sırasıyla Smith ve Knight diş aşınma indeksi (TWI) ve çürük, eksik ve dolgulu dişler indeksi (DMFT) kullanılarak değerlendirildi. Ayrıca ağız içerisindeki şikayetler de değerlendirildi. Uyarılmış tükürük örnekleri toplandı ve tükürük tamponlama kapasitesi, pH ve akış hızı değerleri ölçüldü.

Bulgular: GÖRH grubunda üst dişlerin palatinal yüzeyinde aşınma görülürken, kontrol grubunda aşınma gözlenmedi $(p<0,05)$. Her iki grupta da üst ön dişlerin insizal yüzeyleri ve üst/alt arka dişlerin oklüzal yüzeylerinin aşınmış olduğu görülmesine rağmen, hasta grubundaki değerler kontrollere göre anlamlı olarak yüksek bulundu $(p<0,05)$. GÖRH grubunda yangılı ağız duyarlılığı, dil hassasiyeti, nonspesifik kaşıntı ve yanma, ağız kokusu, ağız kuruluğu, dişlerde hassasiyet, yumuşak/sert palatinal mukoza/uvulada eritema şikayetlerine kontrol grubundan anlamlı olarak daha sık rastlandı (her biri için $p<0,05$ ). Gruplar DMFT'ye göre benzer bulundu $(p=0,480)$. GÖRH grubunda tükrük akış hızı, pH ve tamponlama kapasitesi değerleri anlamlı olarak düşük bulundu (her biri için $p<0,05$ ).

Sonuç: Çalışmanın sonuçları GÖRH grubundaki katılımcıların üst dişlerinin palatinal yüzeylerinde aşınma olduğunu gösterdi. Ayrıca bu hastaların daha yaygın olarak ağız içi doku değişikliklerinden şikayet ettiklerine ve daha düşük tükürük akış hızı, pH ve tamponlama kapasitesine sahip oldukları da tespit edildi. Bu nedenle diş hekimleri GÖRH'nı ağız sağlığı için potansiyel bir risk faktörü olarak düşünmelidir.

Anahtar Kelimeler: Dental erozyon, gastroözofageal reflü hastalığı, tükürük 


\section{INTRODUCTION}

In the mouth, different forms of chronic degenerative events other than caries affect the teeth. This degeneration appears as wear in the clinic. Based on the etiology and wear rate, dental tissue loss is considered normal or pathological. Functional microwear or attrition usually causes normal wear and this wear progresses to lifelong physiological values. Normal rate of tooth hard tissue loss is approximately $65 \mathrm{~m} / \mathrm{yr}$. When wear occurs in a larger size than expected, it is considered pathological. Pathological loss of dental hard tissue may be due to one or more factors, such as abnormal attrition, abrasion, domestication, attrition, abfraction, resorption, erosion, developmental disorder, etc. ${ }^{[1]}$

Dental erosion, which is a chemical dissolution, occurs as a result of the contact of acidic solutions with the teeth. Any solution below the critical $\mathrm{pH}$ value (approximately 5.5) for the solubility of the enamel layer can cause erosion, especially if the acidic attack is prolonged and repeated. Although saliva and dental pellicle prevent attacks, the destruction of dental tissues is inevitable if the attack is severe and protracted. If erosive lesions progress rapidly, sensitivity increases, but if the progress is slow, the patient may not have any symptoms. However, the entire dentition can be severely damaged. ${ }^{[2]}$

External or internal factors play a role in the etiology of dental erosion. Externally-induced dental erosion may occur as a result of diet, medication use, environmental factors, and lifestyle. ${ }^{[3]}$ The most common cause of internal erosion is "regurgitation," which means that stomach acid enters the mouth and comes into contact with the teeth. This is particularly seen in conditions such as gastroesophageal reflux, anorexia and bulimia nervosa, alcoholism and chronic nausea. ${ }^{[4]}$

The involuntary passage of gastric contents into the esophagus is defined as reflux. Normally, the anatomical position of the gastroesophageal junction, the lower esophageal sphincter and the crural diaphragm prevent the passage of fluid or solids from the stomach to the esophagus. But, when the lower esophageal sphincter relaxes, the pressure gradient between the stomach and the esophagus disappears, and reflux takes place. The reflux material might reach cervical esophagus, pharynx, and oral cavity. ${ }^{[5]}$ Gastroesophageal reflux is a physiological phenomenon that occurs as a result of short-term acid reflux during the day, and it is eliminated by the buffering effect of saliva and the normal swallowing function before any harm occurs. If acid reflux begins to occur chronically, then pathological gastroesophageal reflux disease (GERD) presents. ${ }^{[6]}$ As a result of gastroesophageal reflux, the gastric fluid's $\mathrm{pH}(\sim 1-2)$ decreases the $\mathrm{pH}$ in the mouth below the enamel's critical $\mathrm{pH}^{\left[{ }^{[7]}\right.}$ The contact of gastric contents with teeth and other oral structures should be considered a potential risk factor for the formation of dental erosion and oral lesions. In previous studies, oral cavity lesions and tooth damage caused by reflux material were reported at different frequencies. ${ }^{[8,9]}$
The present study aimed to investigate the relationship between gastroesophageal reflux and dental erosion and the alterations in oral tissues as a result of reflux.

\section{MATERIAL AND METHOD}

\section{Study Setting and Participants}

This case-control study was conducted in Ankara University Faculty of Dentistry, Department of Restorative Dentistry Polyclinics and Ankara University Faculty of Medicine, Department of Gastroenterology Polyclinics with a total of 100 participants (49 females and 51 males between the ages of 1665) of whom 50 were in the GERD group, and 50 were in the control group. Participants diagnosed with GERD were included in the GERD group, and those without the disease were included in the control group. Ethical approval of the study protocol was granted by the Ankara University Faculty of Dentistry Research Ethics Committee (2008/131-2). The study was performed following the principles and the guidelines of the Declaration of Helsinki Ethical Principles. Each human subject signed an informed consent before participating to the study.

The GERD group included 25 females and 25 males with at least one year of reflux symptoms, endoscopic esophagitis, no systemic disease other than reflux, no medication use except anti-reflux drugs, no habit of ruminating and vomiting, and no habit of bruxism. Those who were vegetarian, consumed citrus and vinegar frequently, and consumed more than $1 / 2$ liter of acidic beverages per day were not included in the study. Those who never brush their teeth and were using battery/rechargeable and scrub brush and abrasive toothpaste were not included in the study, either.

The reflux diagnosis was made by a gastroenterologist using detailed patient history and examination and endoscopy, when needed. The patients were questioned according to the burning sensation behind the breastbone and the history of regurgitation. In the endoscopy, esophagitis was sought and graded from $A$ to $D$ with the Los Angeles classification (10). The control group included 24 females and 26 males without any systemic disorder, no habit of ruminant and vomiting, no habit of bruxism, and no drug use. The control group was determined by gender matching with the GERD group.

\section{Data Collection}

The study participants' sociodemographic characteristics, nutrition habits, oral hygiene habits, and oral complaints were assessed to determine the presence of risk factors for dental erosion.

Oral complaints of the participants were evaluated according to the answers given to the questions regarding oral burning sensation, tongue sensitivity, nonspecific itching and burning in the mucosa, halitosis, dry mouth, and increased tooth sensitivity. The presence of erythema in the soft/hard palatal mucosa/uvula was determined by oral examination. In the GERD group, the duration of reflux symptoms and whether regurgitation was 
present and, if so, how often did it occur were recorded. The grade of esophagitis was recorded from the endoscopy reports of the patients, and the duration of anti-reflux treatment and specific medications were collected from the patient charts.

Oral and dental examinations of the study groups were performed by the researcher (F.A.B.) insufficient daylight using a mirror and sond. The intraoral examinations were performed according to the decayed, missing, and filled teeth (DMFT) index and Smith and Knight tooth wear index (TWI) classification. DMFT index is the sum of the number of decayed, missing, and filled teeth. TWI was performed on the cervical, buccal/labial, lingual/palatinal and occlusal/incisal surfaces of the teeth at 0-4 scores ${ }^{[11]}$ The scoring of TWI was shown in the Table 1. Besides, the soft/hard palatal mucosa/uvula was evaluated regarding presence of erythema. All participants were examined once and dental data were collected. After the oral examination, stimulated saliva samples were collected. Then, salivary buffering capacity, $\mathrm{pH}$ and flow rate were determined from the collected samples.

\section{Statistical Analysis}

All analyses of the present study were performed using IBM SPSS Statistics 25 program. Descriptive statistics of the data were given as number, frequency (percentage), mean, standard deviation, median, minimum and maximum. For the normalty check, the Shapiro-Wilk test was used. Normally distributed variables were analyzed with the Independent Samples t Test or one way ANOVA test. Non-normally distributed variables were analyzed with the Mann Whitney U test or Kruskall Wallis test. Categorical variables were analyzed with the Pearson's chisquare test and Fisher exact test. The statistical significance level was set as $p<0.05$.

\begin{tabular}{|c|c|c|c|c|c|}
\hline Parameter & Groups & Mean士SD & Median & Min.-Max. & p \\
\hline \multirow[t]{2}{*}{ DMFT } & GERD & $10.9 \pm 6.58$ & 10 & $1-27$ & \multirow{2}{*}{0.480} \\
\hline & Control & $10.06 \pm 5.18$ & 10 & $2-22$ & \\
\hline \multirow{2}{*}{ Flow rate } & GERD & $1.490 \pm 0.589$ & 1.27 & $0.40-3.08$ & \multirow{2}{*}{$0.042^{*}$} \\
\hline & Control & $1.726 \pm 0.552$ & 1.63 & $0.80-3.40$ & \\
\hline \multirow{2}{*}{$\mathrm{pH}^{* *}$} & GERD & $7.262 \pm 0.263$ & 7.2 & $6.60-7.90$ & \multirow{2}{*}{$0.020^{*}$} \\
\hline & Control & $7.392 \pm 0.297$ & 7.35 & $6.70-8.10$ & \\
\hline \multirow{2}{*}{$\begin{array}{l}\text { Buffering } \\
\text { capacity }^{* *}\end{array}$} & GERD & $3.99 \pm 1.14$ & 3.9 & $1.40-6.30$ & \multirow{2}{*}{$0.000 *$} \\
\hline & Control & $4.95 \pm 0.81$ & 5 & $3.37-6.49$ & \\
\hline
\end{tabular}

\section{RESULTS}

In this study a total of 100 participants were evaluated. 50\% $(n=25)$ of the participants in the GERD group are women and $50 \%(n=25)$ are men and, 49\% $(n=24)$ of the participants in the control group were female and $51 \%(n=26)$ were male $(p=0.841)$. The mean age of the GERD group was $42.92 \pm 11.5$, and the mean age of the control group was $33.16 \pm 9.63$. Compared to the control group, the age of the GERD group was significantly higher $(p=0.000)$.

\section{Dental Caries and Salivary Protection}

The mean values of the DMFT, salivary buffering capacity, $\mathrm{pH}$ and flow rate parameters for the GERD and control groups are shown in Table 2. No difference was found between the groups in terms of the DMFT parameter $(p=0.480)$, whereas the mean salivary buffering capacity, $\mathrm{pH}$ and flow rate values were significantly lower in the GERD group compared to the control group ( $p=0.042, p=0.020, p=0.000$, respectively).

\section{Oral Complaints}

The distribution of oral complaints in the groups are shown in Table 3. It was found that oral complaints were significantly more common in the GERD group than in the control group $(p<0.05)$.

Table 3. Distribution of oral complaints parameters of GERD and control groups.

\begin{tabular}{|c|c|c|c|c|c|c|}
\hline \multirow{3}{*}{ Oral complaints } & & \multicolumn{4}{|c|}{ Groups } & \multirow{3}{*}{$\mathbf{p}$} \\
\hline & & \multicolumn{2}{|c|}{ GERD } & \multicolumn{2}{|c|}{ Control } & \\
\hline & & $n$ & $\%$ & $n$ & $\%$ & \\
\hline \multirow{2}{*}{ Oral burning sensation } & Not have & 34 & 40.5 & 50 & 59.5 & \multirow{2}{*}{$0.000 *$} \\
\hline & Have & 16 & 100.0 & 0 & 0.0 & \\
\hline \multirow{2}{*}{ Tongue sensitivity } & Not have & 39 & 43.8 & 50 & 56.2 & \multirow{2}{*}{$0.000^{*}$} \\
\hline & Have & 11 & 100.0 & 0 & 0.0 & \\
\hline \multirow{2}{*}{$\begin{array}{l}\text { Nonspecific itching/ } \\
\text { burning }\end{array}$} & Not have & 37 & 43.0 & 49 & 57.0 & \multirow{2}{*}{$0.001^{*}$} \\
\hline & Have & 13 & 92.9 & 1 & 7.1 & \\
\hline \multirow{2}{*}{ Halitosis } & Not have & 18 & 36.0 & 32 & 64.0 & \multirow{2}{*}{$0.005^{*}$} \\
\hline & Have & 32 & 64.0 & 18 & 36.0 & \\
\hline \multirow{2}{*}{ Dry mouth } & Not have & 12 & 25.5 & 35 & 74.5 & \multirow{2}{*}{$0.000 *$} \\
\hline & Have & 38 & 71.7 & 15 & 28.3 & \\
\hline \multirow{2}{*}{ Sensitivity of teeth } & Not have & 25 & 38.5 & 40 & 61.5 & \multirow{2}{*}{$0.002^{*}$} \\
\hline & Have & 25 & 71.4 & 10 & 28.6 & \\
\hline \multirow{2}{*}{$\begin{array}{l}\text { Erythema of soft/hard } \\
\text { palatinal mucosa/uvula }\end{array}$} & Not have & 30 & 37.5 & 50 & 62.5 & \multirow{2}{*}{$0.000^{*}$} \\
\hline & Have & 20 & 100.0 & 0 & 0.0 & \\
\hline
\end{tabular}

\begin{tabular}{|c|c|c|}
\hline Score & Surface & Criteria \\
\hline 0 & $\begin{array}{l}\mathrm{B} / \mathrm{L} / \mathrm{O} / \mathrm{I} \\
\mathrm{C}\end{array}$ & $\begin{array}{l}\text { No loss of enamel surface characteristics. } \\
\text { No loss of contour. }\end{array}$ \\
\hline 1 & $\begin{array}{l}\mathrm{B} / \mathrm{L} / \mathrm{O} / \mathrm{I} \\
\mathrm{C}\end{array}$ & $\begin{array}{l}\text { Loss of enamel surface characteristics. } \\
\text { Minimal loss of contour. }\end{array}$ \\
\hline 2 & $\begin{array}{l}\mathrm{B} / \mathrm{L} / \mathrm{O} \\
\mathrm{I} \\
\mathrm{C}\end{array}$ & $\begin{array}{l}\text { Loss of enamel exposing dentine for less than one third of surface. } \\
\text { Loss of enamel just exposing dentine. } \\
\text { Defect less than } 1 \mathrm{~mm} \text { deep. }\end{array}$ \\
\hline 3 & $\begin{array}{l}\mathrm{B} / \mathrm{L} / \mathrm{O} \\
\mathrm{I} \\
\mathrm{C}\end{array}$ & $\begin{array}{l}\text { Loss of enamel exposing dentine for more than one third of surface. } \\
\text { Loss of enamel and substantial loss of dentine. } \\
\text { Defect less than } 1-2 \mathrm{~mm} \text { deep. }\end{array}$ \\
\hline 4 & $\begin{array}{l}\mathrm{B} / \mathrm{L} / \mathrm{O} \\
\mathrm{I} \\
\mathrm{C}\end{array}$ & $\begin{array}{l}\text { Complete enamel loss-pulp exposure-secondary dentin exposure. } \\
\text { Pulp exposure or exposure of secondary dentine. } \\
\text { Defect more than } 2 \mathrm{~mm} \text { deep-pulp exposure-secondary dentine exposure. }\end{array}$ \\
\hline
\end{tabular}




\section{Dental Wear}

The distribution of TWI values of individuals in GERD and control groups are shown in Table 4. As a result of the evaluation of all teeth between 7-7 in the maxillary and mandibular arch using the TWI in the GERD and control groups, the difference between the groups in the cervical and buccal/labial surfaces of the maxillary teeth, the cervical, buccal/labial surfaces of the mandibular posterior teeth, and cervical ve occlusal/incisal surfaces of the mandibular anterior teeth was not significant. Wear was not observed on the buccal/labial surfaces of the mandibular anterior teeth and the lingual surfaces of the mandibular anterior/ posterior teeth in both groups ( $p>0.05)$. However, for the incisal and palatal surfaces of the maxillary anterior teeth, the occlusal and palatal surfaces of the maxillary posterior teeth, and the occlusal surfaces of the mandibular posterior teeth, the difference between the groups was statistically significant $(p<0.05)$.

Wear was observed in the palatal surfaces of the maxillary teeth in the GERD group, while no wear was observed in the control group. Although some wears were observed in both groups, in the occlusal surfaces of maxillary/mandibular posterior teeth and the incisal surfaces of the maxillary anterior teeth, the values in the GERD group were higher than control group (Table 4).

\section{Relationship of GERD with Oral Compaints, Dental Caries and Salivary Protection}

There was no statistically significant difference between the two groups in terms of nutrition and oral hygiene habits ( $p>$ 0.05 , for each).

It was determined that $14 \%(n=7)$ of the participants in the GERD group had reflux complaints for 12 months, 30\% $(n=15)$ of the participants in the GERD group had reflux complaints between 13 and 36 months, and 56\% $(n=28)$ of the participants in the GERD group had reflux complaints for more than 36 months. Of these participants, 30\% $(n=15)$ had regurgitation every day, 34\% $(n=17)$ frequently, $28 \%$ $(n=14)$ occasionally and $8 \%(n=4)$ had no regurgitation. The distribution of the participants in the GERD group in terms of esophagitis grading was determined as $50 \%(n=25)$ Grade $A$, 46\% ( $n=23)$ Grade B and 4\% (n=2) Grade C stage.

There was no statistically significant relationship between oral complaints and GERD duration ( $p>0.05$, for each) (Table 5). Also, there was no statistically significant relationship between the DMFT, salivary flow rate, ph, buffering capacity and GERD duration ( $p>0.05$, for each) (Table 6).

The relationship between the oral complaints and levels of regurgitation frequency (every day, frequently, occasionally, none) were evaluated and no statistically significant relationship was found ( $p>0.05$, for each) (Table 7 ). The relationship of the DMFT, salivary flow rate and $\mathrm{pH}$ with regurgitation frequency was not statistically significant ( $p>0.05$, for each) (Table 8).
Table 4. Distribution of cervical, buccal/labial, incisal/occlusal and palatinal/ lingual surface TWI values of the maxillary and mandibular teeth of GERD and control groups.

\begin{tabular}{|c|c|c|c|c|c|c|c|c|}
\hline \multirow{3}{*}{ 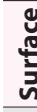 } & & \multirow{3}{*}{ 悉 } & \multirow{3}{*}{$\begin{array}{l}\text { TWI } \\
\text { Score }\end{array}$} & \multicolumn{4}{|c|}{ Groups } & \multirow{3}{*}{ p } \\
\hline & & & & \multicolumn{2}{|c|}{ GERD } & \multicolumn{2}{|c|}{ Control } & \\
\hline & & & & $\mathbf{n}$ & $\%$ & $\mathbf{n}$ & $\%$ & \\
\hline \multirow{17}{*}{ 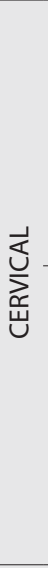 } & \multirow{8}{*}{ 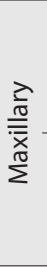 } & \multirow{4}{*}{ Anterior } & 0 & 226 & 46.2 & 263 & 53.8 & \multirow{4}{*}{0.683} \\
\hline & & & 1 & 7 & 50.0 & 7 & 50.0 & \\
\hline & & & 2 & 1 & 100.0 & 0 & 0.0 & \\
\hline & & & Total & 234 & 46.4 & 270 & 53.6 & \\
\hline & & & 0 & 225 & 43.9 & 288 & 56.1 & \multirow{4}{*}{0.928} \\
\hline & & & 1 & 11 & 44.0 & 14 & 56.0 & \\
\hline & & Posterior & 2 & 5 & 50.0 & 5 & 50.0 & \\
\hline & & & Total & 241 & 44.0 & 307 & 56.0 & \\
\hline & \multirow{9}{*}{$\begin{array}{l}\frac{\pi}{\bar{T}} \\
\frac{0}{0} \\
\overline{\overline{0}} \\
\frac{1}{2} \\
\sum\end{array}$} & & 0 & 261 & 48.7 & 275 & 51.3 & \multirow{4}{*}{1.000} \\
\hline & & & 1 & 14 & 50.0 & 14 & 50.0 & \\
\hline & & Anterıor & 2 & 1 & 50.0 & 1 & 50.0 & \\
\hline & & & Total & 276 & 48.8 & 290 & 51.2 & \\
\hline & & & 0 & 246 & 46.6 & 282 & 53.4 & \\
\hline & & & 1 & 15 & 45.5 & 18 & 54.5 & \\
\hline & & Posterior & 2 & 4 & 57.1 & 3 & 42.9 & 0.941 \\
\hline & & & 3 & 1 & 50.0 & 1 & 50.0 & \\
\hline & & & Total & 266 & 46.6 & 304 & 53.4 & \\
\hline & & & 0 & 240 & 47.5 & 265 & 52.5 & \\
\hline & & Anterior & 2 & 1 & 100.0 & 0 & 0 & 0.476 \\
\hline$\vec{\sigma}$ & $\stackrel{\pi}{=}$ & & Total & 241 & 47.6 & 265 & 52.4 & \\
\hline क्र & $\underset{\substack{x\\
}}{x}$ & & 0 & 246 & 44.9 & 302 & 55.1 & \\
\hline$\lesseqgtr$ & & Posterior & 1 & 1 & 100.0 & 0 & 0.0 & 0.450 \\
\hline ᄅे & & & Total & 247 & 45.0 & 302 & 55.0 & \\
\hline ن & $\frac{\frac{\pi}{5}}{\frac{1}{2}}$ & Anterior & 0 & 283 & 49.5 & 289 & 50.5 & - \\
\hline & 믈 & & 0 & 272 & 47.2 & 304 & 52.8 & \\
\hline & $\underset{\sigma}{\frac{\pi}{\sigma}}$ & Posterior & 1 & 3 & 100.0 & 0 & 0.0 & 0.107 \\
\hline & $\Sigma$ & & Total & 275 & 47.5 & 304 & 52.5 & \\
\hline & & & 0 & 27 & 15.3 & 150 & 84.7 & \\
\hline & & & 1 & 105 & 52.8 & 94 & 47.2 & \\
\hline & & Anterior & 2 & 102 & 85.0 & 18 & 15.0 & $0.000^{*}$ \\
\hline & & & 3 & 6 & 85.7 & 1 & 14.3 & \\
\hline & $\stackrel{\bar{\pi}}{=}$ & & Total & 240 & 47.7 & 263 & 52.3 & \\
\hline & 希 & & 0 & 83 & 34.4 & 158 & 65.6 & \\
\hline & & & 1 & 73 & 68.2 & 34 & 31.8 & \\
\hline 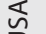 & & Posterior & 2 & 45 & 100.0 & 0 & 0.0 & $0.000^{*}$ \\
\hline 3 & & & 3 & 2 & 100.0 & 0 & 0.0 & \\
\hline . & & & Total & 203 & 51.4 & 192 & 48.6 & \\
\hline 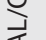 & & & 0 & 113 & 48.1 & 122 & 51.9 & \\
\hline$\underline{\mathbb{}}$ & & & 1 & 139 & 49.6 & 141 & 50.4 & \\
\hline $\bar{z}$ & & Anterior & 2 & 29 & 53.7 & 25 & 46.3 & 0.908 \\
\hline & $\frac{\sqrt{\frac{\pi}{7}}}{7}$ & & 3 & 2 & 50.0 & 2 & 50.0 & \\
\hline & 을 & & Total & 283 & 49.4 & 290 & 50.6 & \\
\hline & ¿ & & 0 & 73 & 30.9 & 163 & 69.1 & \\
\hline & $\sum^{\pi}$ & & 1 & 109 & 71.1 & 46 & 28.3 & \\
\hline & & Posterior & 2 & 59 & 100.0 & 0 & 0.0 & $0.000^{*}$ \\
\hline & & & 3 & 2 & 100.0 & 0 & 0.0 & \\
\hline & & & Total & 243 & 54.1 & 206 & 45.9 & \\
\hline & & & 0 & 50 & 16.7 & 249 & 83.3 & \\
\hline & & & 1 & 59 & 100.0 & 0 & 0.0 & \\
\hline & & Anterior & 2 & 118 & 100.0 & 0 & 0.0 & $0.000^{*}$ \\
\hline & & & 3 & 13 & 100.0 & 0 & 0.0 & \\
\hline$\vec{\nwarrow}$ & $\stackrel{\bar{\pi}}{=}$ & & Total & 240 & 49.1 & 249 & 50.9 & \\
\hline ? & 㐫 & & 0 & 144 & 32.7 & 297 & 67.3 & \\
\hline z & $\Sigma$ & & 1 & 84 & 100.0 & 0 & 0.0 & \\
\hline 卫 & & Posterior & 2 & 15 & 100.0 & 0 & 0.0 & $0.000^{*}$ \\
\hline 这 & & & 3 & 1 & 100.0 & 0 & 0.0 & \\
\hline 3 & & & Total & 244 & 45.1 & 297 & 54.9 & \\
\hline & $\frac{\bar{\pi}}{\overline{3}}$ & Anterior & 0 & 281 & 49.3 & 289 & 50.7 & - \\
\hline & $\sum^{\frac{N}{\pi}}$ & Posterior & 0 & 276 & 47.2 & 309 & 52.8 & - \\
\hline
\end{tabular}


Table 5. The relationship between duration of GERD and oral complaints.

\begin{tabular}{|c|c|c|c|c|c|c|c|c|}
\hline & & \multicolumn{6}{|c|}{ GERD duration } & $\mathbf{p}$ \\
\hline Oral burning sensation & Not have & 5 & 14.7 & 8 & 23.5 & 21 & 61.8 & 0.36 \\
\hline \multirow{2}{*}{ Tongue sensitivity } & Not have & 6 & 15.4 & 11 & 28.2 & 22 & 56.4 & \multirow{2}{*}{0.899} \\
\hline & Have & 1 & 9.1 & 4 & 36.4 & 6 & 54.4 & \\
\hline Nonspecific itching/burning & Not have & 7 & 18.9 & 10 & 27.0 & 20 & 54.1 & 0.210 \\
\hline \multirow{2}{*}{ Halitosis } & Not have & 2 & 11.1 & 3 & 16.7 & 13 & 72.2 & \multirow{2}{*}{0.245} \\
\hline & Have & 5 & 15.6 & 12 & 37.5 & 15 & 46.9 & \\
\hline \multirow{2}{*}{ Dry mouth } & Not have & 2 & 16.7 & 2 & 16.7 & 8 & 66.7 & \multirow{2}{*}{0.578} \\
\hline & Have & 5 & 13.2 & 13 & 34.2 & 20 & 52.6 & \\
\hline \multirow{2}{*}{ Sensitivity of teeth } & Not have & 5 & 20.0 & 7 & 28.0 & 13 & 52.0 & \multirow{2}{*}{0.536} \\
\hline & Have & 2 & 8.0 & 8 & 32.0 & 15 & 60.0 & \\
\hline
\end{tabular}

Table 6. Comparison of the means of DMFT, salivary flow rate, pH and buffering capacity according to GERD duration.

\begin{tabular}{|c|c|c|c|c|}
\hline Parameter & GERD duration & Mean \pm SD & Median (Min.-Max.) & $\mathbf{p}$ \\
\hline & 12 months & $9.8571 \pm 7.35818$ & $8(1-20)$ & \\
\hline $\mathrm{DMFT}^{* *}$ & 13-36 months & $10.4 \pm 8.57571$ & $7(2-27)$ & 0.453 \\
\hline & More than 36 months & $11.4286 \pm 5.25941$ & $11(4-24)$ & \\
\hline \multirow[t]{2}{*}{ Flow rate } & $13-36$ months & $1.4693 \pm 0.55969$ & $1.28(0.8-2.56)$ & 0.915 \\
\hline & More than 36 months & $1.4796 \pm 0.60914$ & $1.32(0.4-3.08)$ & \\
\hline & More than 36 months & $7.2393 \pm 0.26435$ & $7.2(6.6-7.8)$ & \\
\hline & 12 months & $4.4429 \pm 1.25812$ & $3.9(3-5.9)$ & \\
\hline \multirow[t]{2}{*}{ Buffering capacity } & $13-36$ months & $4.12 \pm 1.20071$ & $4.1(1.4-6.3)$ & 0.362 \\
\hline & More than 36 months & $3.8 \pm 1.07909$ & $3.6(1.5-6.2)$ & \\
\hline
\end{tabular}

Table 7. The relationship between regurgitation frequency and oral complaints.

Regurgitation Frequency

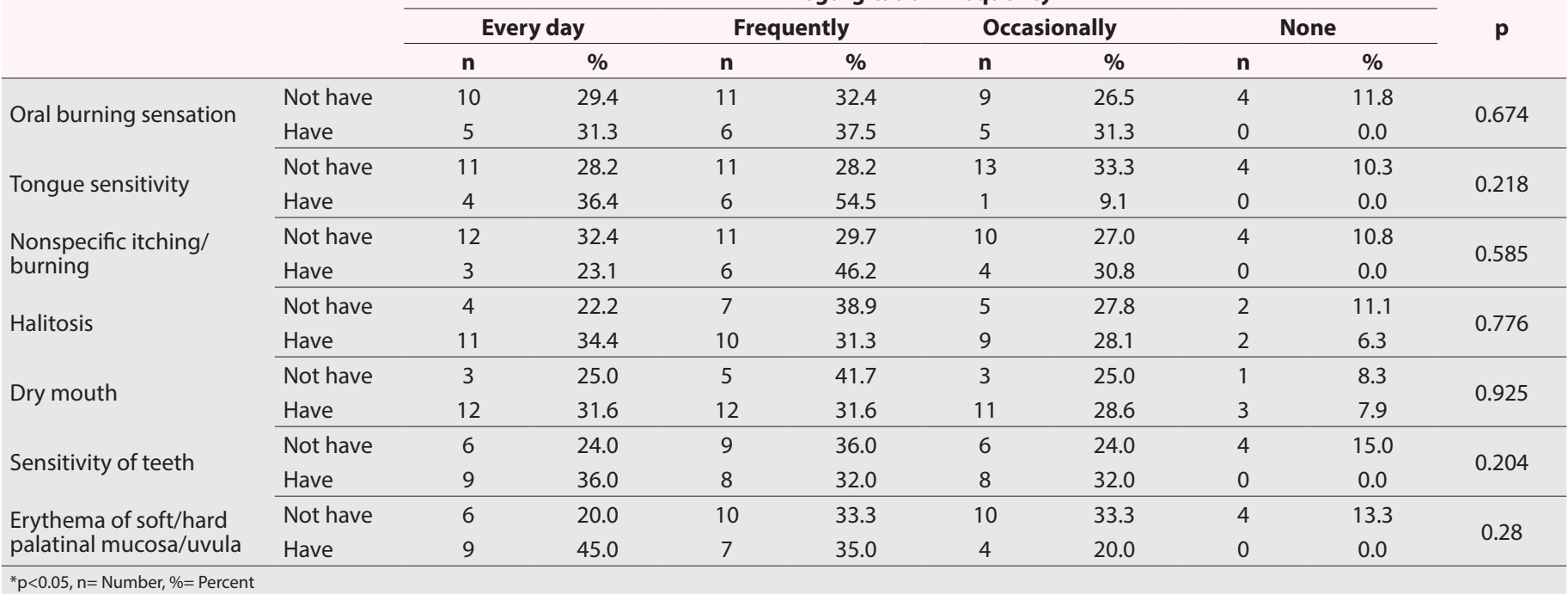




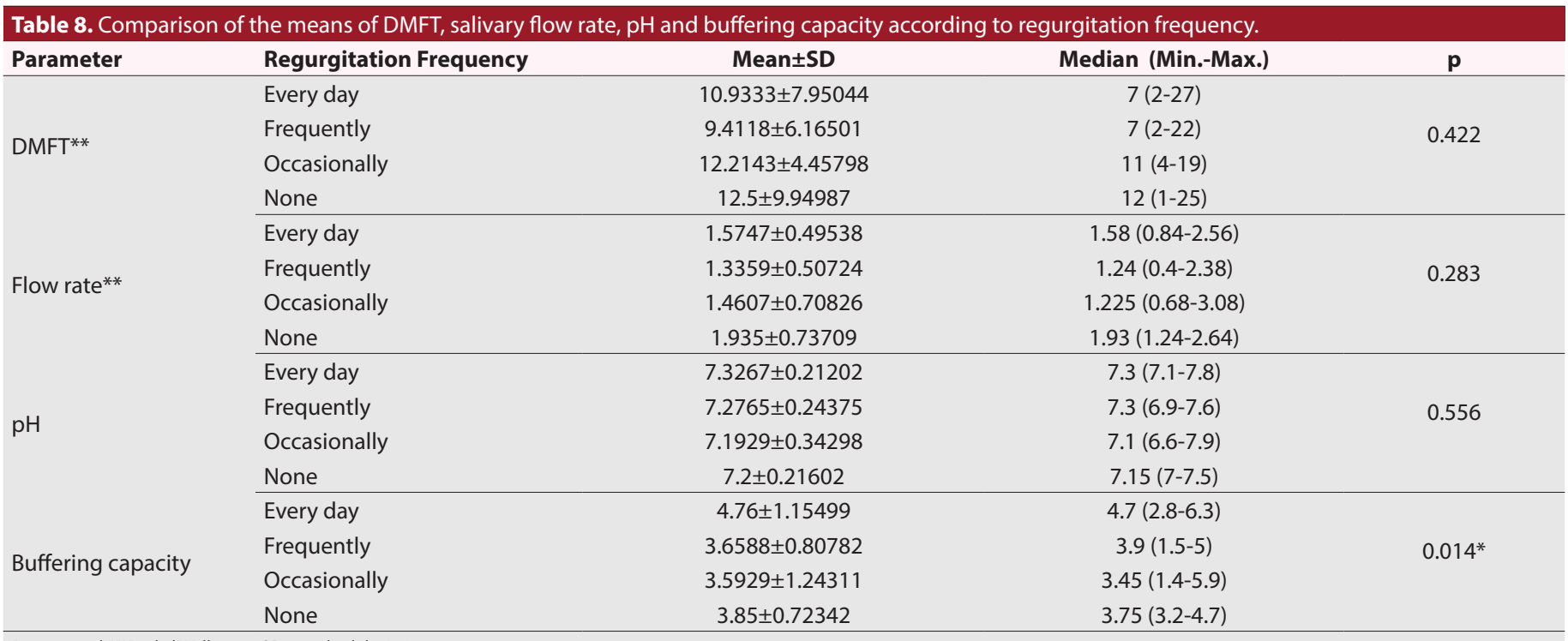

${ }^{*} p<0.05$ and ${ }^{* *}$ Kruskal Wallis test, SD: standard deviation

The relationship of the salivary buffering capacity with regurgitation frequency was statistically significant $(p=0.014)$. Accordingly, statistically significant differences were obtained between those who had regurgitation every day and those who had regurgitation frequently and occasionally $(p=0.029$, $p=0.027$, respectively).

It was noticed that the medications using for treatment did not effect the salivary buffering capacity, $\mathrm{pH}$ and flow rate values ( $p>0.05$, for each) (Table 9).

\begin{tabular}{|c|c|c|c|c|}
\hline Parameter & $\begin{array}{l}\text { Medication } \\
\text { use }\end{array}$ & Mean \pm SD & $\begin{array}{c}\text { Median } \\
\text { (Min.-Max.) }\end{array}$ & $\mathbf{p}$ \\
\hline \multirow{2}{*}{ Flow rate ${ }^{* *}$} & Not use & $10.9 \pm 6.57841$ & $1.28(1-27)$ & \multirow{2}{*}{0.841} \\
\hline & Use & $1.4389 \pm 0.47495$ & $1.26(0.8-2.56)$ & \\
\hline \multirow{2}{*}{$\mathrm{pH}$} & Not use & $1.5219 \pm 0.65517$ & $7.2(0.4-3.08)$ & \multirow{2}{*}{0.894} \\
\hline & Use & $1.4904 \pm 0.58934$ & $7.2(0.4-3.08)$ & \\
\hline \multirow{2}{*}{$\begin{array}{l}\text { Buffering } \\
\text { capacity** }^{* *}\end{array}$} & Not use & $7.2684 \pm 0.23107$ & $3.9(7-7.6)$ & \multirow{2}{*}{0.589} \\
\hline & Use & $7.2581 \pm 0.28493$ & $3.6(6.6-7.9)$ & \\
\hline
\end{tabular}

\section{DISCUSSION}

In the present study, it was aimed to investigate the relationship between GERD and the loss of tooth tissues, and TWI was used to evaluate the erosion in teeth. Also, the saliva samples, which were considered a very important biological factor for the occurrence of dental erosion, were collected from all individuals to compare the buffering capacity, $\mathrm{pH}$ and flow rate of saliva in the GERD and control groups.

The salient findings of the present study were as follows: the wear values on the palatal surfaces of the maxillary teeth, on the incisal surfaces of the maxillary anterior teeth, and on the occlusal surfaces of the maxillary/mandibular posterior teeth were higher in the GERD group. The wear scores on the other surfaces were similar in the groups. Further, the salivary buffering capacity, $\mathrm{pH}$ and flow rate values were lower in the GERD group than in the control group.

The acids usually involved in dental erosion are of intrinsic or extrinsic origin. Usually intrinsic factors are from regurgitated gastric juices and extrinsic factors are from dietary, medicinal, occupational, and recreational sources. Bartlett and Coward reported that gastric fluid obtained from GERD patients during endoscopy had much more erosive potential than acidic dietary products. ${ }^{[8]}$ Wang et al. ${ }^{[9]}$ reported that the reflux material in liquid or solid-liquid form can easily reach the oral cavity and then cause erosive damage to the teeth. They also added that the reflux in gas or vapor form may play same role.

Dentition is protected from erosion by various mechanisms of saliva and its components. First, saliva dilutes the erosive material and helps it flow away from the environment by allowing it to flow into the stomach. Saliva protects dental hard tissues against acid attacks by creating saturation on the enamel's outer surface thanks to the presence of calcium and phosphorus, providing pellicle formation on the tooth surface, and also providing the remineralizing ions (Fluor, Calcium, Phosphorus) necessary to convert demineralization to remineralization after erosive attacks. ${ }^{[2,4,12]}$

Moazzez et al. ${ }^{[13]}$ showed that in GERD, wear occured due to the contact of regurgitated gastric acid with the palatal surfaces of the upper incisors, and saliva played an important role in tooth erosion due to its low buffering capacity. Holbrook et al. ${ }^{[14]}$ also emphasized that a low salivary buffering capacity was associated with erosion. Bartlett et al. ${ }^{[15]}$ and Richter ${ }^{[16]}$ stated that acid reflux primarily affects the palatal surfaces of the upper incisors. This was explained by the fact that gastric juice first hit the palatal surface of the upper teeth and continued contact with acid for a longer period of time, 
that the palatal surfaces were relatively farther away from the major salivary glands, and that the tongue's protection of the lower teeth was greater than in the palatal region. They added that if the acidic effect persists, other surfaces of the maxillary posterior and mandibular teeth may also be affected. The results of this study support the view that the most affected area is the palatal surface of the maxillary anterior teeth. The ability of saliva to clear acid is important for the development of dental erosion. The speed of the saliva's movement can vary greatly in different parts of the mouth. Teeth near the areas where saliva flows into the mouth, such as the lower anterior and upper posterior teeth, benefit from a higher salivary clearance. In the middle interproximal and anterior maxillary areas where saliva has more difficulty to reaching, clearance is slower and $\mathrm{pH}$ returns to normal late. [17,18]

In the present study, the prevalence of GERD patients (82\%) with dental erosions was higher than that reported by Meurman et al. ${ }^{[19]}$ (24\%), Schroeder et al. ${ }^{[20]}(55 \%)$, Munoz et al. ${ }^{[21]}$ and Benages et al. ${ }^{[22]}$ (47.5\%). but similar to that of Bartlett et al. ${ }^{[23]}(64 \%)$ and Tugut et al. ${ }^{[24]}(80 \%)$. This variance regarding dental erosions among the studies might be due to many factors, including, but not limited to, the diagnostic criteria used, dietary habits, frequency and content of regurgitation, saliva characteristics, frictional force caused by the tongue during swallowing and phonation, and the presence of restorations.

Some factors influencing the formation of dental erosions are dependent on the individual, whereas some other are completely independent. The buffering capacity of saliva and the solubility of the teeth against acids are factors that are independent of the individual, while general health status and dietary habits depend on the individual. It has been frequently mentioned that dietary acids, especially in fruit juices and carbonated beverages, cause erosion. ${ }^{[25-28]}$ In the present study, no significant difference was observed between the groups in terms of dietary habits. This result also lends support that GERD was the primary cause of dental erosions observed in the patients.

According to some studies, clinical signs of dental erosions occur when acid contacts the teeth several times a week for at least 1-2 years. ${ }^{[4]}$ In the current study, all patients had at least 12 months of regurgitation, while $26(62 \%)$ patients had this symptom more than 36 months. Regurgitation was observed daily or frequently in $67 \%$ and occasionally in $33 \%$ of the patients. Moreover, the ability of saliva to neutralize acid affects the formation of erosion by protecting the teeth and oral cavity with dilution and its salivary buffering capacity. It is thought that individuals with low flow rates are five times more at risk for erosion than those with normal flow rates. ${ }^{[29]}$ When the buffering capacity is deteriorated, acid is also more dangerous for oral tissues. ${ }^{[30]}$ In general, dental erosion appears when the protective buffering capacity of the oral cavity is overcome by either reduced salivary secretion or increased volume of injurious gastric refluxate. ${ }^{[31]}$
In the present study, the findings related to dry mouth, oral acid/burning sensation, halitosis, and erythema of the soft/ hard palatal mucosa/uvula were in line with previous studies, and this was thought to be caused by direct contact of acid reflux with oral tissues. ${ }^{[30,32,34]}$ In terms of dental sensitivity parameters, Di Fede et al. ${ }^{[34]}$ showed discrepant results. This can be explained by the fact that the duration, amount, and frequency of gastric acid contact with the tissues, the saliva characteristics, or the erosion value between the studies were different.

Some limitations of the present study deserve mention; first, the case and control groups were not matched according to age. Since the age of the case group was significantly higher, age-related problems might have affected the patient group more than the control group. This may have caused a selection bias. Second, since the study examined 50 cases and 50 healthy participants who applied between certain dates, its generalizability should be evaluated in this respect. Finally, recall bias may have affected the results in the questions asked to the patients.

In this study, the results showed that the loss of dental hard tissues was higher in patients with GERD than in healthy individuals. Dry mouth, halitosis, oral burning sensation, nonspecific itching, teeth sensitivity, tongue sensitivity, and erythema of the soft/hard palatal mucosa/uvula were also associated with GERD. No difference was found between the groups for caries prevalence. Patients with GERD should be considered as a risk group for dental and oral health, and all the necessary prophylactic and therapeutic applications should be performed.

\section{CONCLUSIONS}

In the present study, erosion-related wear was observed in the GERD group, but not in the control group. The wear values observed in the patient group were found to be different concerning the jaws, teeth, and surfaces. It was found that the palatal and incisal/occlusal surfaces of the maxillary teeth had higher scores than the other surfaces. These scores were higher in the anterior region than in the posterior region, whereas the mandibular teeth had high scores in the occlusal surfaces of the posterior teeth. Oral complaints were more frequent in the GERD group, and the salivary buffering capacity, $\mathrm{pH}$ and flow rate values were also lower than in the control group. However, there was no difference between the groups in terms of DMFT.

\section{ETHICAL DECLARATIONS}

Ethics Committee Approval: The study was carried out with the permission of Ankara University Faculty of Dentistry Research Ethics Committee (permission granted: 10.06.2008, decision no: 131/2).

Informed Consent: All patients signed the free and informed consent form. 


\section{Referee Evaluation Process: Externally peer-reviewed.} Conflict of Interest Statement: The authors have no conflicts of interest to declare.

Financial Disclosure: The authors declared that this study has received no financial support.

Author Contributions: All of the authors declare that they have all participated in the design, execution, and analysis of the paper, and that they have approved the final version.

Acknowledgment: We would like to thank Professor Necati Örmeci for enabling us to benefit from the clinical opportunities.

\section{REFERENCES}

1. Gregory-Head B, Curtis DA. Erosion caused by gastroesophageal reflux: diagnostic considerations. J Prosthodont 1997;6(4):278-85.

2. Meurman JH, ten Cate JM. Pathogenesis and modifying factors of dental erosion. Eur J Oral Sci 1996;104(2):199-206.

3. Zero DT. Etiology of dental erosion: extrinsic factors. Eur J Oral Sci 1996;104(2):162-77.

4. Scheutzel P. Etiology of dental erosion-intrinsic factors. Eur J Oral Sci 1996;104(2):178-90.

5. Van Roekel NB. Gastroesophageal reflux disease, tooth erosion, and prosthodontic rehabilitation: a clinical report. J Prosthodont 2003;12(4):255-9.

6. Mousa H, Hassan M. Gastroesophageal reflux disease. Pediatr Clin North Am 2017;64(3):487-505.

7. Bartlett DW, Evans DF, Anggiansah A, Smith BG. The role of the esophagus in dental erosion. Oral Surg Oral Med Oral Pathol Oral Radiol Endod 2000;89(3):312-5.

8. Bartlett DW, Coward PY. Comparison of the erosive potential of gastric juice and a carbonated drink in vitro. J Oral Rehabil 2001;28(11):1045-7.

9. Wang GR, Zhang $\mathrm{H}$, Wang ZG, Jiang GS, Guo $\mathrm{CH}$. Relationship between dental erosion and respiratory symptoms in patients with gastrooesophageal reflux disease. J Dent 2010;38(11):892-8.

10. Lundell LR, Dent J, Bennett JR, et al. Endoscopic assessment of oesophagitis: clinical and functional correlates and further validation of the Los Angeles classification. Gut 1999;45(2):172-80.

11. Smith BG, Knight JK. An index for measuring the wear of teeth. Br Dent J 1984;156(12):435-8.

12. Gudmundsson K, Kristleifsson G, Theodors A, Holbrook WP. Tooth erosion, gastroesophageal reflux, and salivary buffer capacity. Oral Surg Oral Med Oral Pathol Oral Radiol Endod 1995;79(2):185-9.

13. Moazzez R, Bartlett D, Anggiansah A. Dental erosion, gastro-oesophageal reflux disease and saliva: how are they related? J Dent 2004;32(6):489-94.

14. Holbrook WP, Furuholm J, Gudmundsson K, Theodórs A, Meurman JH. Gastric reflux is a significant causative factor of tooth erosion. J Dent Res 2009;88(5):422-6.

15. Bartlett DW, Evans DF, Smith BG. The relationship between gastroesophageal reflux disease and dental erosion. J Oral Rehabil 1996;23(5):289-97.

16. Richter JE. Extraesophageal presantations of gastroesophageal reflux disease. Semin Gastrointest Dis 1997;8(2):75-89.

17. Millward A, Shaw L, Smith A. Dental erosion in four year old children from differing socio-economic backgrounds. ASDC J Dent Child 1994;61(4):263-6.

18. Milosevic A, Young PJ, Lennon MA. The prevalence of tooth wear in 14-year-old school children in Liverpool. Community Dent Health 1994;11(2):83-6.
19. Meurman JH, Toskala J, Nuutinen P, Klemetti E. Oral and dental manifestations in gastroesophageal reflux disease. Oral Surg Oral Med Oral Pathol 1994;78(5):583-9.

20. Schroeder PL, Filler SJ, Ramirez B, Lazarchik DA, Vaezi MF, Richter JE. Dental erosion and acid reflux disease. Ann Intern Med 1995;122(11):809-15.

21. Muñoz JV, Herreros B, Sanchiz V, et al. Dental and periodontal lesions in patients with gastro-oesophageal reflux disease. Dig Liver Dis 2003;35(7):461-7.

22. Benages A, Muñoz JV, Sanchiz V, Mora F, Mínguez M. Dental erosion as extraoesophageal manifestation of gastro-oesophageal reflux. Gut 2006;55(7):1050-1.

23. Bartlett DW, Evans DF, Anggiansah A, Smith BG. A study of the association between gastro-oesophageal reflux and palatal dental erosion. Br Dent $J$ 1996;181(4):125-31.

24. Tugut F, Ozdemir Dogan D, Polat T, Yılmaz K, Ozdemir AK. Prevalence of dental erosion in patients with gastroesophageal reflux disease. CDJ 2009;12(1):29-32.

25. Grobler SR, Senekal PJ, Laubscher JA. In vitro demineralization of enamel by orange juice, apple juice, pepsi cola and diet pepsi cola. Clin Prev Dent 1990;12(5):5-9.

26. Larsen MJ, Nyvad B. Enamel erosion by some soft drinks and orange juices relative to their $\mathrm{pH}$, buffering effect and contents of calcium phosphate. Caries Res 1999;33(1):81-7.

27. Milosevic A, Bardsley PF, Taylor S. Epidemiological studies of tooth wear and dental erosion in 14-year old children in North West England. Part 2: The association of diet and habits. Br Dent J 2004;197(8):479-83.

28. Jensdottir T, Holbrook P, Nauntofte B, Buchwald C, Bardow A. Immediate erosive potential of cola drinks and orange juices. J Dent Res 2006;85(3):226-30.

29. Järvinen VK, Rytömaa II, Heinonen OP. Risk factors in dental erosion. J Dent Res 1991;70(6):942-7.

30. Lazarchik DA, Filler SJ. Effects of gastroesophageal reflux on the oral cavity. Am J Med 1997;103(5):107-3.

31. Farrokhi F, Vaezi MF. Extra esophageal manifestations of gastroesophageal reflux. Oral Dis 2007;13(4):349-59.

32. Järvinen V, Meurman JH, Hyvärinen H, Rytömaa I, Murtomaa H. Dental erosion and upper gastrointestinal disorders. Oral Surg Oral Med Oral Pathol 1988;65(3):298-303.

33. DeVault KR. Should upper gastrointestinal endoscopy be part of the evaluation for supraesophageal symptoms of GERD? Am J Gastroenterol 2004;99(8):1427-9.

34. Di Fede O, Di Liberto C, Occhipinti G, et al. Oral manifestations in patients with gastro oesophageal reflux disease: a single-center case-control study. J Oral Pathol Med 2008;37(6):336-40. 